\title{
Quantitative Analysis of Male Fetal DNA in Maternal Serum of Gravid Rhesus Monkeys (Macaca mulatta)
}

\author{
DANIEL F. JIMENEZ AND ALICE F. TARANTAL \\ California National Primate Research Center [D.F.J., A.F.T.] and Department of Pediatrics [A.F.T.], \\ University of California, Davis, CA 95616-8542, U.S.A.
}

\begin{abstract}
ABST
The isolation of human fetal DNA from the maternal circu-
lation has provided a source of fetal material for prenatal diag-
nosis. The objective of this study was to investigate whether a
similar pattern could be observed in the maternal circulation of
male-bearing gravid rhesus monkeys. A real-time PCR TaqMan
system for the rhesus Y-chromosome sex determining region was
used to determine fetal sex and to quantify fetal DNA concen-
trations. Results in 14 healthy pregnancies indicated that fetal
male DNA could be routinely detected in maternal serum by $50 \mathrm{~d}$
of gestation (late first trimester; term $165 \pm 10$ d). Fetal DNA
concentrations increased with advancing gestation, reaching a
mean of 341 genome equivalents/mL of serum (range $11-1570$
copies/mL) in the last trimester of gestation, similar to findings in
\end{abstract}
The discovery of high levels of fetal nucleic acids in the maternal circulation has opened up new areas of investigation and provided a potential new approach for prenatal molecular diagnosis (1). The isolation of cell-free fetal DNA has been shown to be useful material for fetal sex determination and screening for pregnancy-related complications and fetal disease $(2,3)$. Furthermore, this technique can potentially be applied to investigate other developmental questions associated with the level and degree of fetomaternal trafficking, maintenance of the fetal allograft and tolerance induction, and maternal autoimmune diseases such as scleroderma (4-14). For exploring such fields of study, appropriate animal models that closely simulate human development and disease are needed.

Received April 30, 2002; accepted July 26, 2002.

Correspondence: Alice F. Tarantal, Ph.D., California National Primate Research Center, University of California, Pedrick \& Hutchison Roads, Davis, CA 95616-8542; e-mail: aftarantal@primate.ucdavis.edu

These studies were supported by NIH Grants HL69748, HL53762, DK53711, and RR00169.

DOI: 10.1203/01.PDR.0000039837.34834.65 humans. The fetal DNA concentration corresponded to $2.7 \%$ of the total maternal serum DNA in the third trimester. Similar to findings in humans, male fetal DNA sequences were not detected postpartum (through 4 wk postpartum) or in animals with a previous history of delivering male offspring. These data indicate that fetal male DNA is present in the maternal circulation of gravid rhesus monkeys comparable to findings in humans and further support the use of this nonhuman primate species as a model to investigate fetomaternal cell trafficking and microchimerism. (Pediatr Res 53: 18-23, 2003)

\section{Abbreviation}

SRY, Y-chromosome sex-determining region
Studies in nonhuman primates, specifically macaques, have shown similarities in anatomy, developmental biology, hematology, and immunology that have prompted the use of this species as a model in fetal and pediatric research (15-20). Monkeys and humans share many characteristic features because of their close phylogenetic relationship. Developmental similarities include spatial and temporal pattern of organ development, placental structure, and length of gestation. Unlike rodents and sheep, human and nonhuman primates (monkeys) have a similar placental structure, which highlights the importance of this model for addressing questions related to transplacental trafficking of fetal cells and DNA.

In this study, we investigated the presence of male fetal rhesus DNA in maternal serum during the length of gestation. In addition, the $\epsilon$-globin gene was used to quantify total (i.e. fetal and maternal) DNA concentrations in maternal serum. We addressed these questions by developing specific, highly sensitive and reproducible methods to quantify rhesus genomic DNA by real-time TaqMan PCR assays (21). The results of this study demonstrate that fetal rhesus DNA sequences can be detected reliably in early gestation and throughout the second 
and third trimesters of pregnancy. In addition, similarities in the kinetics of fetal male DNA were found when compared with the data obtained from human studies (22).

\section{METHODS}

Animals. All animal procedures conformed to the requirements of the Animal Welfare Act, and protocols were approved before implementation by the Institutional Animal Use and Care Administrative Advisory Committee at the University of California at Davis. Twenty normal, adult female rhesus monkeys (Macaca mulatta) ranging in age from 6 to $12 \mathrm{y}$ and body weights of 5.4-9.6 kg with a history of previous pregnancies (between 1 and 9) were bred and identified as pregnant, using established methods (23). Fourteen of these animals were pregnant with male fetuses, and six animals were pregnant with female fetuses, of which three had a previous pregnancy with a male fetus (range of previous male pregnancies 2-4). Pregnancy in rhesus monkeys is divided into trimesters by $55-\mathrm{d}$ increments: $0-55 \mathrm{~d}$ of gestation represents the first trimester, $56-110 \mathrm{~d}$ of gestation represents the second trimester, and $111-165 \mathrm{~d}$ of gestation represents the third trimester (term 165 \pm 10 d) (24). All animals were examined sonographically during gestation (23), and healthy newborns were delivered by cesarean section at term. Sex was identified prenatally by ultrasound (23) and confirmed at delivery.

Blood sample collection and nucleic acid isolation. Blood samples $(2-12 \mathrm{~mL})$ were collected from gravid animals every $10 \mathrm{~d}$ from $20 \mathrm{~d}$ of gestation until term $(160 \mathrm{~d})$. Of these samples, eight aliquots per animal $(200 \mu \mathrm{L}$ serum/aliquot) were chosen spanning $20-160 \mathrm{~d}$ and each of the trimesters for use in the TaqMan assay. A subset of animals with male fetuses $(n=4)$ also had samples collected weekly from the day of delivery until 1 mo postpartum. Samples were obtained from a peripheral vessel and placed into anticoagulant-free Vacutainers. Serum was collected using established techniques and after samples were allowed to clot, then immediately placed on ice until centrifugation. All specimens were centrifuged at $1500 \mathrm{rpm}$ for $10 \mathrm{~min}$. The serum was then transferred to a microcentrifuge tube and centrifuged at $8000 \mathrm{rpm}$ for $5 \mathrm{~min}$. The supernatants were collected into new microcentrifuge tubes, then stored at $-70^{\circ} \mathrm{C}$ until further processing. All samples were processed immediately after collection and frozen once the serum was aliquoted. DNA was isolated from 200 $\mu \mathrm{L}$ of serum using the QIAamp DNA Blood Kit (Qiagen, Valencia, CA), as recommended by the manufacturer.

Genomic DNA was also isolated from control male and female rhesus liver samples collected at necropsy as part of other published studies (25) and human male peripheral blood mononuclear cells. The genomic DNA was extracted by using the Gentra System DNA isolation kit (Gentra, Minneapolis, $\mathrm{MN}$ ), as previously reported (25). DNA samples from the rhesus monkey were used as positive (male) and negative (female) controls in all PCR reactions. Additional negative controls run in each assay consisted of water in the reaction mix. Human genomic DNA was used to confirm that there was no cross-reactivity in the assay (see below).
Real-time quantitative PCR. Real-time quantitative PCR was performed using an Applied Biosystems 7700 System Detector (Foster City, CA) (21). The primers and probe sequences were designed with Primer Express software (PerkinElmer, Foster City, CA). Sequence data were obtained from the GenBank Sequence Database [accession numbers AF284310, Macaca mulatta sex determining region Y (SRY) and M81364 ( $\epsilon$-globin gene)]. To avoid false positives by crosscontamination from human male operators, the TaqMan system for the rhesus monkey was designed such that it would not amplify the corresponding human Y-chromosome region. This was accomplished by obtaining the human Y-chromosome region from the GenBank Sequence Database (accession numbers L10102; Homo sapiens SRY gene). Differences in the sequence between the human and rhesus monkey Ychromosome regions for the primer and probe design were obtained after alignment of both sequences using BLAST (Basic Local Alignment Search Tool). The system was designed with two mismatched nucleotides in the sequence for the reverse primer and five nucleotides in the probe (see below).

The SRY TaqMan system was synthesized and purified by PE Biosystems (Foster City, CA), and the $\epsilon$-globin TaqMan system was synthesized and purified by Synthetic Genetics (San Diego, CA). The internal probe was labeled at the $5^{\prime}$ end with the reporter dye FAM (6-carboxyfluorescein) and at the 3' end with the quencher dye TAMRA (6-carboxytetramethylrhodamine) and was phosphate-blocked at the $3^{\prime}$ end to prevent extension by the DNA polymerase. The primers for the rhesus male-specific sequence were as follows: forward SRY-569F: 5'-CGGAAGGCGAAGATGCTG-3'; reverse SRY-634R: 5'GCAGGGTACCGAAGAGGGA-3'. The probe in this system was as follows: SRY-589T: 5'-FAM-AAACAGTTGCAGTTTGCTTCCGGCA-3'.

The $\epsilon$-globin TaqMan system consisted of the amplification primers as follows: forward $\epsilon$-globin-1494F: 5'-TGGCAAGGAGTTCACCCCT-3'; reverse $\epsilon$-globin-1557R: 5'-AATGGCGACAGCAGACACC-3'; and a probe for $\epsilon$-globin-1517T: 5'-TGCAGGCTGCCTGGCAGAAGC-3'.

Amplification conditions were identical for all reactions. The thermal profile was as follows: $2 \mathrm{~min}$ at $50^{\circ} \mathrm{C}, 10 \mathrm{~min}$ at $95^{\circ} \mathrm{C}, 45$ cycles of $15 \mathrm{~s}$ at $95^{\circ} \mathrm{C}$, and $60 \mathrm{~s}$ at $60^{\circ} \mathrm{C}$. The amplification reactions were set in a final volume of $25 \mu \mathrm{L}$, containing $20 \mu \mathrm{L}$ of $2 \times$ TaqMan Universal Mastermix (PE Biosystems) with $10 \mathrm{mM}$ Tris (pH 8.3), $50 \mathrm{mM} \mathrm{KCl}, 5 \mathrm{mM}$ $\mathrm{MgCl}_{2}, 2.5 \mathrm{mM}$ deoxynucleotide triphosphates, $0.625 \mathrm{U}$ of AmpliTaq Gold per reaction, and $5 \mu \mathrm{L}$ of the diluted DNA sample. For all TaqMan assays, primer and probe concentrations were 400 and $100 \mathrm{nM}$, respectively.

For each sample, parallel reactions were run in duplicate in separate wells for the detection of male rhesus Y sequence and $\epsilon$-globin genes. The mean result was used for further analysis. Amplification data were analyzed by the sequence detection system software (version 1.6.3; Applied Biosystems). The concentrations of SRY and $\epsilon$-globin sequences were expressed in genome equivalents or copies per milliliter and calculated, as previously described (22). For preventing contamination during DNA extraction, PCR amplification, and the detection 
of PCR products, procedures were performed in accordance with standards previously described $(26,27)$. The TaqMan assay also included anticontamination measures in the form of preamplification treatment with uracil N-glycosylase (28).

Linear range and amplification efficiencies of TaqMan primers and probes. For determining the linearity and amplification efficiencies, five 10 -fold dilution steps of male rhesus genomic DNA were amplified in triplicate. The average threshold cycle values $\left(C_{\mathrm{T}}\right)$ were plotted against the log quantities of target genomic DNA and the regression line was calculated (Fig. 1). The resulting standard curve was linear for five logarithmic decades in the $\epsilon$-globin and SRY systems. The efficiency of the reaction (E) was calculated from the slope of the standard dilution series, as previously described (29). For reducing the variability in the assay, a constant amount of carrier DNA polydeoxyadenylic-thymidylic acid (Sigma Chemical Co, St. Louis, MO) was added to the diluted samples to minimize the amount of genomic DNA absorbed to the walls of the tube.

Statistical analysis. Statistical analysis was performed using statistical software (StatView 512+, version 4.5, Brainpower Inc, Calabasas, CA). The mean copy number of SRY and $\epsilon$-globin sequences was compared between first (20-50 d), second (60-100 d), and third trimesters (110-160 d) using the

\section{Epsilonglobin}
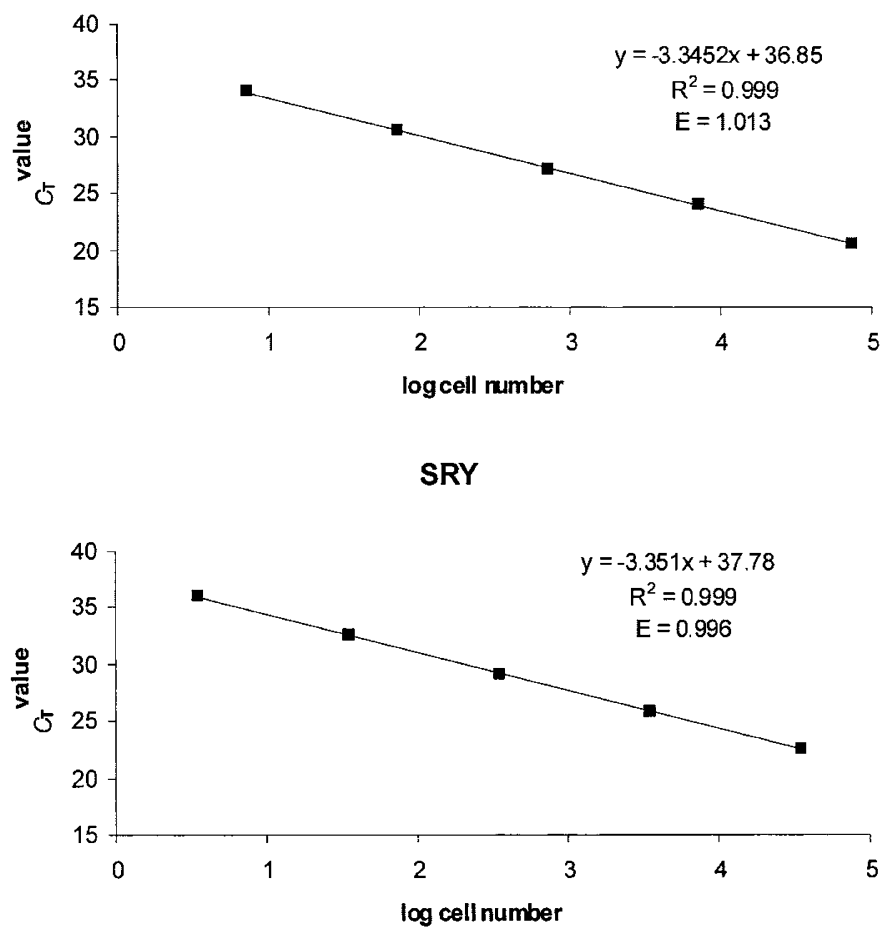

Figure 1. Standard curves for the real-time PCR TaqMan assays. Isolated male genomic DNA was used as a standard for the estimation of the linear range and amplification efficiencies of the SRY and $\epsilon$-globin real-time PCR systems. The copy number was calculated after optical density (OD) measurements were collected at $260 \mathrm{~nm}$. Five 10-fold dilutions were made in PCRgrade water containing $10 \mu \mathrm{g}$ of polydeoxyadenylic-thymidylic acid per sample as carrier DNA. Each sample dilution was measured in triplicate. The linear regression equation, correlation $\left(\mathrm{R}^{2}\right)$, and reaction efficiency $(\mathrm{E})$ are illustrated.
Mann-Whitney rank sum test (30). Statistical significance was assigned to all values where $p<0.05$.

\section{RESULTS}

Linear range and amplification efficiencies of TaqMan primers and probes. Quantitation of SRY and $\epsilon$-globin sequences showed linearity over 5 orders of magnitude. Both real-time SRY and $\epsilon$-globin systems were sufficiently sensitive to detect the DNA equivalent to one cell (data not shown). The SRY assay was insensitive to the existence of background female rhesus DNA from 0 to 12,800 genome equivalents, and no PCR amplification was detected with human male DNA samples.

Precision determination. To determine the precision of both real-time PCR TaqMan assays, we determined the coefficient of variability within run and between runs, as previously described (31) (see Table 1). To assess the precision within run, we measured eight times within one run the target amount of SRY and $\epsilon$-globin sequences present in the genomic DNA sample equivalent to $2.5,25,250$, and 2500 cells and to 5,50 , 500 , and 5000 cells, respectively. The cell equivalent was calculated from optical density (OD) measurements collected at $260 \mathrm{~nm}$ and by the use of a conversion factor of $6.6 \mathrm{pg}$ of DNA per cell, as previously described (32). All samples were positive with both real-time PCR systems. Coefficients of variation $(\mathrm{CV})$ were calculated on the basis of the $C_{\mathrm{T}}$ values $\left[\mathrm{CV}\left(C_{\mathrm{T}}\right)\right]$ and of absolute values $[\mathrm{CV}(\mathrm{Abs})]$ after transformation with the standard curve. The $\mathrm{CV}\left(\mathrm{C}_{\mathrm{T}}\right)$ for the SRY and $\epsilon$-globin of the within-run precision systems was in the range of $0.4-2.1 \%$, the CV (Abs) was in the range of $4.5-41.9 \%$ (see Table 1).

To assess the precision between runs, we evaluated the four dilutions of genomic DNA (equivalent to 5, 50, 500, and 5000 cells) by using TaqMan PCR on five separate runs. The CV $\left(C_{\mathrm{T}}\right)$ between-run experiments for both systems was in the range of $0.5-16.0 \%$, and the $\mathrm{CV}$ (Abs) was in the range of $10.8-48.9 \%$. In general, the results from the within-run and the between-run experiments showed increased precision with higher amounts of starting genomic DNA.

Quantitative analysis of G-globin using the TaqMan system. For each animal, DNA was extracted from maternal serum at eight time points between 20 and $160 \mathrm{~d}$ of gestation, with a subset of animals evaluated for 1 mo postpartum (see "Methods"). The $\epsilon$-globin system was used as an internal control for the isolation of DNA from maternal serum samples and to calculate the total amount of cell-free circulating DNA (both maternal and fetal). Data analysis showed a consistent increase with each subsequent trimester in the concentration of fetal $\epsilon$-globin sequences (see Table 2 ). This increase is statistically significant $(p<0.007)$ only when the first and third trimesters of gestation are compared.

Quantitative analysis of fetal SRY in maternal serum. Real-time quantitative PCR analysis using the SRY TaqMan system was carried out to calculate the amount of circulating fetal male DNA. Quantitative data on the concentration of SRY sequences during gestation are summarized in Table 3. Isolation of DNA from $200 \mu \mathrm{L}$ of serum consistently produced 
Table 1. Coefficients of variability in within-run and between-run precision for SRY and e-globin TaqMan assays using serum from gravid rhesus monkeys (Macaca mulatta) (values represent percentages)

\begin{tabular}{|c|c|c|c|c|c|c|c|c|}
\hline \multirow[b]{2}{*}{ Copy \#/DNA } & \multicolumn{4}{|c|}{ SRY (\%) } & \multicolumn{4}{|c|}{$\varepsilon$-globin $(\%)$} \\
\hline & 2500 & 250 & 25 & 2.5 & 5000 & 500 & 50 & 5 \\
\hline \multicolumn{9}{|l|}{$\mathrm{CV}\left(\mathrm{C}_{\mathrm{T}}\right)$} \\
\hline Between-runs & 0.50 & 0.48 & 1.26 & 2.66 & 0.55 & 0.63 & 1.36 & 16.00 \\
\hline \multicolumn{9}{|l|}{$\mathrm{CV}(\mathrm{Abs})$} \\
\hline Within-run & 4.50 & 8.32 & 28.37 & 41.89 & 6.20 & 10.39 & 24.45 & 41.75 \\
\hline Between-runs & 10.80 & 10.52 & 29.35 & 52.61 & 12.30 & 15.30 & 30.47 & 48.89 \\
\hline
\end{tabular}

Table 2. Comparison of the mean copy numbers of the $\varepsilon$-globin sequences in the circulation of gravid monkeys during gestation.

\begin{tabular}{cccr}
\hline & Mean \pm SEM & Median & \multicolumn{1}{c}{ Range } \\
\hline 1st trimester & & & \\
20-50 days & $3,103.6 \pm 853.1$ & 1,862 & $342-17,379$ \\
2nd trimester & & & \\
$\quad 60-100$ days & $6,844.4 \pm 1,799.5$ & 3,535 & $141-55,818$ \\
3rd trimester* & & & \\
$110-120$ days & $10,022.0 \pm 3,590.7$ & 5,852 & $553-76,109$ \\
$130-160$ days & $13,959.3 \pm 3,020.2$ & 8,317 & $2,092-80,333$ \\
$110-160$ days & $12,580.9 \pm 2,349.7$ & 7,220 & $553-80,333$ \\
\hline
\end{tabular}

All data are represented as copies $/ \mathrm{mL}$

SEM, standard error of the mean.

* Statistically significant difference when compared to other gestational time points $(p<0.01)$.

Table 3. Comparison of the mean copy numbers of $Y$ chromosome sequences (SRY) in the circulation of gravid monkeys with a male fetus during gestation

\begin{tabular}{cccc}
\hline & Mean \pm SEM & Median & Range \\
\hline 1st trimester: & & & \\
20-50 days & $10.2 \pm 2.8$ & 7.8 & $0-46$ \\
2nd trimester: & & & \\
60-100 days & $91.4 \pm 15.0$ & 59.9 & $12-487$ \\
3rd trimester*: & & & \\
$110-120$ days & $102.9 \pm 20.9$ & 87.5 & $11-249$ \\
$130-160$ days & $422.4 \pm 56.3$ & 317.3 & $38-1,570$ \\
$110-160$ days & $340.9 \pm 46.2$ & 212.2 & $11-1,570$
\end{tabular}

All data represented as copies $/ \mathrm{mL}$.

SEM, standard error of the mean.

* Statistically significant difference when compared to other gestational time points $(p<0.01)$.

amplification of SRY sequences by $50 \mathrm{~d}$ of gestation in all animals with male fetuses. In a subset of animals (approximately $40 \%$ ), SRY sequences were also detected by $30 \mathrm{~d}$ of gestation. These data also indicated that the mean concentrations of fetal male DNA in maternal serum were statistically increased with each subsequent trimester $(p<0.001)$. The greatest developmental rise in male rhesus DNA was observed in the last month of pregnancy (130-160 d of gestation; Fig. 2).

The fractional concentration of fetal DNA in maternal serum in the second and third trimesters of pregnancy was shown to be $0.9 \%$ and $2.7 \%$, respectively. Male fetal DNA sequences were not detected in the subset of animals evaluated postpartum. In addition, none of the dams that bore female fetuses in the current pregnancy and that had previously delivered male offspring (between two and four previous male fetuses) were found to have male fetal DNA in collected serum.

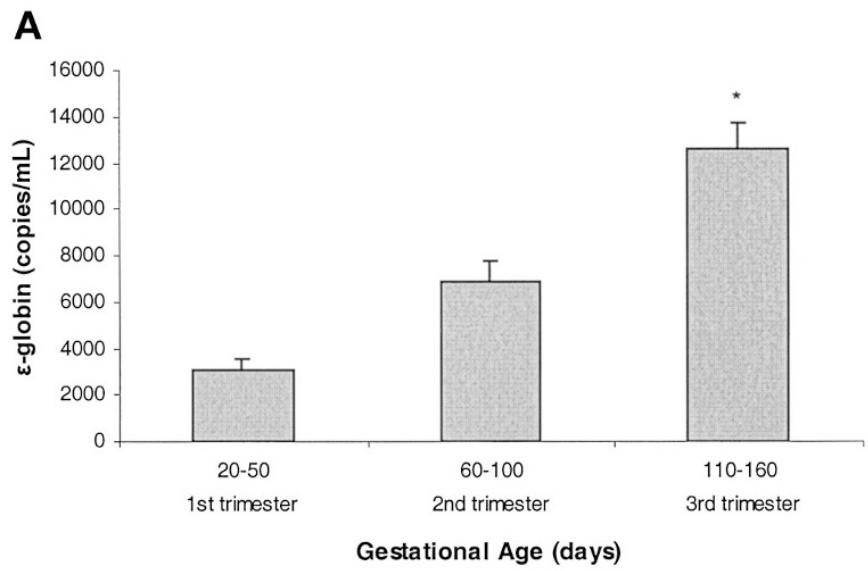

B

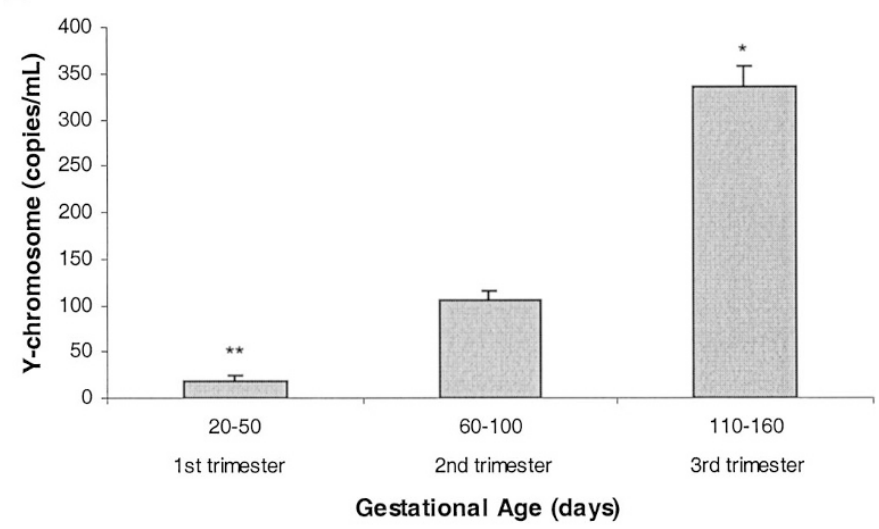

Figure 2. Fetal rhesus $\epsilon$-globin and male DNA in the maternal circulation. Fourteen animals with male fetuses were evaluated during gestation (first trimester to term; see text) $(A)$. $\epsilon$-globin was used as an internal control. $\epsilon$-globin sequences in the maternal circulation were detected in all animals during all trimesters of gestation, with an approximate doubling with each subsequent trimester $\left({ }^{*} p<0.005\right)$. During the first trimester $(20-50 \mathrm{~d}$ of gestation), all animals showed male DNA sequences in the maternal circulation but at low copy numbers $(B)$. The greatest levels of fetal Y-chromosome DNA in the maternal circulation were observed in the third trimester, with the most significant elevations observed after $130 \mathrm{~d}$ of gestation, or approximately $1 \mathrm{mo}$ before delivery $(* p<0.001 ; * * \mathrm{p}<0.005)$.

\section{DISCUSSION}

The results of this study show that fetal male DNA sequences can be found in the circulation of gravid rhesus monkeys during the course of gestation. Previous studies in humans have demonstrated that fetal DNA is present at high concentrations in the maternal circulation, particularly in the third trimester $(1,2,22)$. In the study described here, we used a specific and quantitative assay for the Y-chromosome se- 
quences of the rhesus monkey that do not cross-react with human $\mathrm{Y}$. This technique is similar to one we previously reported using routine PCR techniques (33). We also developed a real-time TaqMan PCR system to calculate the quantity of total DNA in the circulation of gravid monkeys using the $\epsilon$-globin gene. The fluorogenic TaqMan system has been shown to be a fast, simple, and reliable method to quantify genomic DNA (31). Both the SRY and $\epsilon$-globin systems have ranges of linear quantification over 5-6 log decades $(21,34)$, and the results on the amplification efficiency and precision determination are in agreement with other TaqMan systems validated in previous studies $(29,35)$. The specificity of the SRY assay was preserved, as we did not observe amplification signals in animals from a previous pregnancy or in gravid monkeys carrying a female fetus or genomic DNA from human male samples.

Studies in humans have shown that fetal male sequences can be detected as early as weeks 5-7 of gestation (22), and recent reviews indicate the molecular analysis of fetal DNA is feasible at the beginning of the second trimester (5). In our study, amplification of SRY sequences was possible in a subset of animals at $35 \pm 5 \mathrm{~d}$ of gestation (data not shown). However, using the techniques described, we consistently detected SRY sequences by the end of the first trimester ( $50 \mathrm{~d}$ of gestation). Preliminary results in our laboratory suggest that increasing the volume of maternal serum can increase the sensitivity of the TaqMan assay and the ability to detect reliably male offspring at earlier gestational time points $(25 \pm 5 \mathrm{~d}$ of gestation) (Jimenez and Tarantal, submitted). In the current study, we used $200 \mu \mathrm{L}$ of maternal serum, whereas in human studies up to $800 \mu \mathrm{L}$ was used. Another possible alternative to increase assay sensitivity is to design a PCR system that targets the repetitive regions of the $\mathrm{Y}$ chromosome. However, it has been shown that, in some cases, this strategy can produce falsepositive results $(36,37)$.

The concentration of fetal male DNA (SRY sequences) was shown to increase significantly with the progression of pregnancy. The kinetics of male fetal rhesus DNA during gestation are similar to those previously reported in human subjects by Lo et al. (22). Other studies have also shown higher transplacental trafficking of fetal DNA toward the end of gestation (7). Although the biologic basis by which fetal DNA is released with increasing quantity into the maternal circulation remains to be elucidated, it has been hypothesized that fetal cell-free DNA may be released after cell lysis by immunologic processes, physical damage, or developmentally associated apoptosis within the placenta $(1,22,27,38)$.

Several studies have evaluated the presence of human fetal DNA in the maternal circulation, although none have addressed whether there is a parallel increase in total DNA (fetal and maternal) with advancing gestation. In the study described here, we observed an increase in total DNA over the course of pregnancy. However, recent data have shown that concentrations of cell-free genomic DNA can be up to 20- to 100-fold higher when evaluated in serum and compared with plasma (39). This difference has been attributed to the cell-free DNA generated during the process of clotting and as a result of lysis of nucleated cells present in whole blood. To address this issue, we previously calculated the quantity of fetal and total DNA in serum versus plasma in two animals during each trimester of gestation (data not shown). This study showed a 0.4-fold increase (range 0.002-1.3) in Y-chromosome copies when comparing serum with plasma, whereas a 10-fold increase (range 2-16) in total DNA was observed. The slight differences in values when comparing $\mathrm{Y}$-chromosome copies obtained from serum versus plasma are most likely due to the scarcity of fetal cells in the maternal circulation, which has been reported to be one fetal cell in $10^{7}$ maternal cells $(40,41)$. Furthermore, it has been shown that the concentrations of cell-free fetal DNA and total DNA in maternal plasma can fluctuate between 2.2- and 13.5-fold, respectively. These results suggest that care should be taken when considering the total DNA cell-free fraction, particularly when using serum samples (42). Thus, we cannot definitively conclude that an increase in total DNA occurs with each subsequent trimester; additional investigations will be required to confirm this possibility.

Our studies have also shown that there are differences in the quantity of circulating male fetal DNA when comparing individual nonhuman primates in the last trimester (11-1570 genome equivalents/mL). Similarly, among 25 human pregnancies evaluated, a range of 34-900 male genome equivalents/mL was reported in late pregnancy (22). Whereas some reports have suggested that high levels of fetal DNA in the maternal circulation may be associated with pregnancyassociated abnormalities (43-45), other studies suggest that a 2-fold variation in free fetal DNA can be found in healthy pregnancies over a period of three successive days (46). This further emphasizes that care should be taken when using free fetal DNA elevations as an indicator of pregnancy-related problems. Our observations parallel those reported in human subjects because a comparable 2-fold difference in the amount of male fetal rhesus DNA was found when comparing individual animals with viable, healthy pregnancies and subsequent offspring (data not shown).

In conclusion, we have demonstrated that fetal rhesus DNA can be readily detected in the maternal circulation during gestation and that the kinetics of cell-free DNA are similar to findings in humans. The results of these studies support the importance of the rhesus monkey model for investigations that focus on enhancing our understanding of fetomaternal trafficking and microchimerism and can be applied to explore the potential ramifications of fetal cell and gene transfer treatment strategies from the maternal perspective.

Acknowledgments. We thank Kristen Kralovich, Chang Lee, Kevin Mohler, and the animal care staff at the Primate Center for expert technical assistance and Dr. Peter Barry for manuscript review.

\section{REFERENCES}

1. Lo YM, Corbetta N, Chamberlain PF, Rai V, Sargent IL, Redman CW, Wainscoat JS 1997 Presence of fetal DNA in maternal plasma and serum. Lancet 350:485-487

2. Bianchi DW, Lo YM 2001 Fetomaternal cellular and plasma DNA trafficking: the Yin and the Yang. Ann N Y Acad Sci 945:119-131

3. Lo YM 2001 Circulating nucleic acids in plasma and serum: an overview. Ann N Y Acad Sci 945:1-7 
4. Ober C 1992 The maternal-fetal relationship in human pregnancy: an immunogenetic perspective. Exp Clin Immunogenet 9:1-14

5. Pertl B, Bianchi DW 2001 Fetal DNA in maternal plasma: emerging clinical applications. Obstet Gynecol 98:483-490

6. Tanaka A, Lindor K, Ansari A, Gershwin ME 2000 Fetal microchimerisms in the mother: immunologic implications. Liver Transpl 6:138-143

7. Zhong XY, Holzgreve W, Hahn S 2001 Circulatory fetal and maternal DNA in pregnancies at risk and those affected by preeclampsia. Ann N Y Acad Sci 945:138140

8. Nelson JL, Furst DE, Maloney S, Gooley T, Evans PC, Smith A, Bean MA, Ober C, Bianchi DW 1998 Microchimerism and HLA-compatible relationships of pregnancy in scleroderma. Lancet 351:559-562

9. Nelson JL 1998 Pregnancy, persistent microchimerism, and autoimmune disease. J Am Med Womens Assoc 53:31-32

10. Aractingi S, Uzan S, Dausset J, Carosella ED 2000 Microchimerism in human diseases. Immunol Today 21:116-118

11. Connolly MK, McCalmont TH 1998 Fetal DNA and cells in women with systemic sclerosis. N Engl J Med 339:771-772

12. Daniell HW 1998 Fetal DNA and cells in women with systemic sclerosis. N Engl J Med 339:772

13. Evans PC, Lambert N, Maloney S, Furst DE, Moore JM, Nelson JL 1999 Long-term fetal microchimerism in peripheral blood mononuclear cell subsets in healthy women and women with scleroderma. Blood 93:2033-2037

14. Maloney S, Smith A, Furst DE, Myerson D, Rupert K, Evans PC, Nelson JL 1999 Microchimerism of maternal origin persists into adult life. J Clin Invest 104:41-47

15. Cowan MJ, Chou S-H, Tarantal AF 2001 Tolerance induction post in utero stem cel transplantation. In: Holzgreve W, Lessl M (eds) Stem Cells from Cord Blood, In Utero Stem Cell Development, and Transplantation-Inclusive Gene Therapy, Ernst Schering Research Foundation Workshop \#33. Springer-Verlag, New York, NY, pp 145-196

16. Tarantal AF, Gargosky SE 1995 Characterization of the insulin-like growth factor axis in the fetal macaque (Macaca mulatta and Macaca fascicularis): a crosssectional study. Growth Reg 5:190-198

17. Tarantal AF, Han VKM, Cochrum KC, Mok A, daSilva M, Matsell DG 2001 Feta rhesus monkey model of obstructive renal dysplasia. Kidney Int 59:446-456

18. Tarantal AF, Hunter MK, Gargosky SE 1997 Direct administration of insulin-like growth factor to fetal rhesus monkeys (Macaca mulatta). Endocrinology 138:33493358

19. Tarantal AF, Marthas ML, Shaw J-P, Cundy K, Bischofberger N 1999 Administration of 9-[2-(R)-(phosphonylmethoxy)propyl]adenine (PMPA) to gravid and infant rhesus macaques (Macaca mulatta): safety and efficacy studies. J Acquir Immune Defic Syndr Hum Retrovirol 20:323-333

20. Tarantal AF, Salamat MS, Britt WJ, Luciw P, Hendrickx AG, Barry PA 1998 Neuropathogenesis induced by rhesus cytomegalovirus in fetal rhesus monkeys (Macaca mulatta). J Infect Dis 177:446-450

21. Heid CA, Stevens J, Livak KJ, Williams PM 1996 Real time quantitative PCR Genome Res 6:986-994

22. Lo YM, Tein MS, Lau TK, Haines CJ, Leung TN, Poon PM, Wainscoat JS, Johnson PJ, Chang AM, Hjelm NM 1998 Quantitative analysis of fetal DNA in maternal plasma and serum: implications for noninvasive prenatal diagnosis. Am J Hum Genet 62:768-775

23. Tarantal AF, Hendrickx AG 1988 Use of ultrasound for early pregnancy detection in the rhesus and cynomolgus macaque (Macaca mulatta and Macaca fascicularis). J Med Primatol 17:105-112

24. Tarantal AF, Gargosky SE, Ellis DS, O’Brien Jr WD, Hendrickx AG 1995 Hematologic and growth-related effects of frequent prenatal ultrasound exposure in the long-tailed macaque (Macaca fascicularis). Ultrasound Med Biol 21:1073-1081

25. Tarantal AF, O'Rourke JP, Case SS, Newbound GC, Li J, Lee CI, Baskin CR, Kohn DB, Bunnell BA 2001 Rhesus monkey model for fetal gene transfer: studies with retroviral-based vector systems. Mol Ther 3:128-138
26. Honda H, Miharu N, Ohashi Y, Ohama K 2001 Successful diagnosis of fetal gender using conventional PCR analysis of maternal serum. Clin Chem 47:41-46

27. Sekizawa A, Watanabe A, Kimura T, Saito H, Yanaihara T, Sato T 1996 Prenata diagnosis of the fetal $\mathrm{RhD}$ blood type using a single fetal nucleated erythrocyte from maternal blood. Obstet Gynecol 87:501-505

28. Longo MC, Berninger MS, Hartley JL 1990 Use of uracil DNA glycosylase to control carry-over contamination in polymerase chain reactions. Gene 93:125-128

29. Klein D, Janda P, Steinborn R, Muller M, Salmons B, Gunzburg WH 1999 Proviral load determination of different feline immunodeficiency virus isolates using real-time polymerase chain reaction: influence of mismatches on quantification. Electrophoresis 20:291-299

30. Haycock AH, Roth J, Gagnon J, Finzer WF, Soper C 1984 StatView for the Macintosh. Abacus Concepts, Inc., Berkeley, CA, pp 343-356

31. Leutenegger CM, Klein D, Hofmann-Lehmann R, Mislin C, Hummel U, Boni J, Boretti F, Guenzburg WH, Lutz H 1999 Rapid feline immunodeficiency virus provirus quantitation by polymerase chain reaction using the TaqMan fluorogenic real-time detection system. J Virol Methods 78:105-116

32. Lo YM, Zhang J, Leung TN, Lau TK, Chang AM, Hjelm NM 1999 Rapid clearance of fetal DNA from maternal plasma. Am J Hum Genet 64:218-224

33. Tarantal AF, Goldstein O, Barley F, Cowan MJ 2000 Transplantation of human peripheral blood stem cells into fetal rhesus monkeys (Macaca mulatta). Transplantation 69:1818-1823

34. Suryanarayana K, Wiltrout TA, Vasquez GM, Hirsch VM, Lifson JD 1998 Plasma SIV RNA viral load determination by real-time quantification of product generation in reverse transcriptase-polymerase chain reaction. AIDS Res Hum Retroviruses 14:183-189

35. Leutenegger CM, Higgins J, Matthews TB, Tarantal AF, Luciw PA, Pedersen NC, North TW 2001 Real-time TaqMan PCR as a specific and more sensitive alternative to the branched-chain DNA assay for quantitation of simian immunodeficiency virus RNA. AIDS Res Hum Retroviruses 17:243-251

36. Naito E, Dewa K, Yamanouchi H, Kominami R 1994 Sex typing of forensic DNA samples using male- and female-specific probes. J Forensic Sci 39:1009-1017

37. Simonic I, Gericke GS, Ott J, Weber JL 1998 Identification of genetic markers associated with Gilles de la Tourette syndrome in an Afrikaner population. Am J Hum Genet 63:839-846

38. Sekizawa A, Samura O, Zhen DK, Falco V, Farina A, Bianchi DW 2000 Apoptosis in fetal nucleated erythrocytes circulating in maternal blood. Prenat Diagn 20:886889

39. Lee T-H, Montalvo L, Chrebtow V, Busch MP 2001 Quantitation of genomic DNA in plasma and serum samples: higher concentrations of genomic DNA found in serum than in plasma. Transfusion 41:276-282

40. Hahn S, Zhong XY, Burk MR, Troeger C, Kang A, Holzgreve W 2001 Both maternal and fetal cell-free DNA in plasma fluctuate. Ann N Y Acad Sci 945:141-144

41. Bianchi DW, Williams JM, Sullivan LM, Hanson FW, Klinger KW, Shuber AP 1997 PCR quantitation of fetal cells in maternal blood in normal and aneuploid pregnancies. Am J Hum Genet 61:822-829

42. Hahn S, Zhong XY, Burk MR, Troeger C, Holzgreve W 2000 Multiplex and real-time quantitative PCR on fetal DNA in maternal plasma. A comparison with fetal cells isolated from maternal blood. Ann N Y Acad Sci 906:148-152

43. Leung TN, Zhang J, Lau TK, Hjelm NM, Lo YM 1998 Maternal plasma fetal DNA as a marker for preterm labour. Lancet 352:1904-1905

44. Leung TN, Zhang J, Lau TK, Chan LY, Lo YM 2001 Increased maternal plasma fetal DNA concentrations in women who eventually develop preeclampsia. Clin Chem 47:137-139

45. Lo YM 2000 Fetal DNA in maternal plasma: biology and diagnostic applications Clin Chem 46:1903-1906

46. Zhong XY, Burk MR, Troeger C, Kang A, Holzgreve W, Hahn S 2000 Fluctuation of maternal and fetal free extracellular circulatory DNA in maternal plasma. Obstet Gynecol 96:991-996 